\title{
A Faster and a Stronger Defense Response: One of the Key Elements in Grapevine Explaining Its Lower Level of Susceptibility to Esca?
}

\author{
Carole Lambert, Ian Li Kim Khiook, Sylvia Lucas, \\ Nadège Télef-Micouleau, Jean-Michel Mérillon, and Stéphanie Cluzet
}

Université de Bordeaux, Groupe d'Etude des Substances Végétales à Activité Biologique (GESVAB), EA 3675, Institut des Sciences de la Vigne et du Vin, 210 Chemin de Leysotte, CS 50008, F-33882 Villenave d'Ornon Cedex, France. Accepted for publication 17 April 2013.

\begin{abstract}
Lambert, C., Khiook, I. L. K., Lucas, S., Télef-Micouleau, N., Mérillon, J.-M., and Cluzet, S. 2013. A faster and a stronger defense response: One of the key elements in grapevine explaining its lower level of susceptibility to Esca? Phytopathology 103:1028-1034.

Wood diseases like Esca are among the most damaging afflictions in grapevine. The defense mechanisms in this plant-pathogen interaction are not well understood. As some grapevine cultivars have been observed to be less susceptible to Esca than others, understanding the factors involved

cultivar ('Cabernet Sauvignon'), and monitored their defense responses at the leaf level. Our model of elicitation consisted in grapevine cuttings absorbing a culture filtrate of one causal agent of Esca, Phaemoniella chlamydospora. This model might reflect the early events occurring in Esca-affected grapevines. The two least susceptible cultivars showed an earlier and stronger defense response than the susceptible one, particularly with regard to induction of the $P A L$ and STS genes, and a higher accumulation of stilbene compounds and some pathogenesis-related proteins.
\end{abstract} in this potentially stronger defense response can be of great interest. To lift part of this veil, we elicited Vitis vinifera plants of two cultivars less susceptible to Esca ('Merlot' and 'Carignan') and of one susceptible
Additional keywords: polyphenols, stilbenoids, wood decay.
Esca disease is an important grapevine trunk affliction occurring worldwide. Besides inducing decreases in grapevine yield and threatening the sustainability of viticulture (10), Esca leads to a loss of wine sensory quality (35). It has become increasingly frequent during the last decade and no effective control exists. Esca is mostly noted in established vineyards but also occurs in newly planted ones (10). The main actors of this disease are two ascomycetes, Phaeomoniella chlamydospora (W. Gams, P. W. Crous, M. J. Wingfield, and L. Mugnai) P. W. Crous \& W. Gams and Phaeoacremonium aleophilum (W. Gams, P. W. Crous, M. J. Wingfield, and L. Mugnai) (19,32), and a basidiomycete, Fomitiporia mediterranea (M. Fischer) (25). These fungi invade the woody tissues of perennial organs and to a lesser extent the annual canes $(32,41)$. However, they have never been reported to be present in leaves where external symptoms are expressed. $P$. chlamydospora and $P$. aleophilum induce black streaking while white rot is caused by $F$. mediterranea $(10,41)$. Two types of external symptoms occur with Esca. The first consists of a severe form, termed apoplexy, which takes the form of sudden leaf wilting, leading to the death of canes or entire plants (41). The other, now termed leaf-stripe disease and mentioned hereafter as the "chronic" form, refers to vines expressing visible foliar symptoms such as light green or chlorotic spots between the leaf veins or along the leaf margins, which then gradually expand and turn yellow brown or red brown, leaving only a narrow strip of green tissue along the main veins (41). These foliar symptoms are thought to be caused at least partially by extracellular molecules produced by the fungi and/or reaction products of the infected wood, which are translocated to the leaves (33). In the case of

Corresponding author: S. Cluzet

E-mail address: stephanie.cluzet@u-bordeaux2.fr

http://dx.doi.org/10.1094/PHYTO-11-12-0305-R

(C) 2013 The American Phytopathological Society
P. chlamydospora, the metabolites that can be produced represent several secondary compounds such as naphthalenone pentaketides (e.g., scytalone and isosclerone) and also secreted toxic polypeptides $(5,10,12,13,36)$.

Beyond the various fungi involved, these diseases reveal the plant's ability to respond to the attack. Indeed, plants are able to counteract pathogenic fungi by establishing various defense strategies such as oxidative stress, cell wall reinforcement, pathogenesis-related (PR) proteins and phytoalexin production (28). Considering the grapevine defense events occurring during Esca disease, little is known about what occurs in the wood, and most data until now concern the plant defense reactions taking place in the leaves. Nevertheless, hydroxystilbenoids (e.g., resveratrol and $\varepsilon$-viniferin), which are phenolics, are known to accumulate in infected wood $(3,4,39)$.

An increase in glutathione depletion was recently observed in the leaves of Esca-affected vines (49). The expression of several genes involved in the defense response was also detected in presymptomatic leaves, and such expression is amplified during symptom expression $(33,37,49)$. The affected genes encode enzymes of the phenylpropanoid pathway (phenylalanine ammonia-lyase and stilbene synthase), PR-proteins (e.g. chitinase, beta-1,3-glucanase, and serine proteinase inhibitor) and detoxification enzymes (e.g., glutathione S-transferase). In addition, Spagnolo et al. (44) reported the accumulation of PR proteins like thaumatin- and osmotin-like proteins in the green stems of Esca-affected plants.

The visual observation of Esca leaf symptoms is the only nondisruptive way to identify Esca in vines, even if occasional discontinuity of these symptoms has been reported from one or more growing seasons to the next $(38,41,46)$. Therefore, to identify affected vines, several continuous years of annual inspection are required $(15,38,41,46)$. Based on annual surveys, different percentages of symptomatic vines can be recorded according to the cultivar, so some cultivars could be more susceptible to Esca than others $(24,32,46)$. The characterization of Esca incidences by the 
French National Grapevine Trunk Diseases Survey (27) and by Christen et al. (17) has allowed the classification of French cultivated cultivars according to their susceptibility to Esca. In both surveys, 'Merlot', 'Carignan', and 'Grenache' demonstrated low susceptibility whereas 'Ugni Blanc', 'Poulsard', 'Sauvignon', and 'Cabernet Sauvignon' were rather susceptible. These differences in susceptibility suggest the presence of intrinsic plant factors responsible for a better defense response. One of the hypotheses regarding these defense mechanisms is the involvement of polyphenols like hydroxystilbenoids, the grapevine phytoalexins $(4,10,39)$. Furthermore, it is widely thought that a crucial factor determining the success of these defense mechanisms is the speed of their activation (22). Consequently, we hypothesized that some grapevine cultivars deal better with Esca thanks to their capacity to activate defense mechanisms more rapidly and/or intensely. For this investigation, we used foliar cuttings of two cultivars less susceptible to Esca ('Merlot' and 'Carignan') and those of a susceptible cultivar ('Cabernet Sauvignon'). We elicited these plants by enabling them to absorb a culture filtrate of $P$. chlamydospora, a causal agent of Esca. This culture medium is known to contain fungal metabolites (e.g., toxins) like those produced in an Esca-affected plant (10). We monitored some defense-marker responses in the leaves of control and treated plants, particularly those of the phenylpropanoid pathway.

\section{MATERIALS AND METHODS}

Plant material. V. vinifera L. 'Cabernet Sauvignon', 'Merlot', and 'Carignan' plants were propagated from wood cuttings in a greenhouse (INRA, Villenave d'Ornon, France). They were grown under controlled conditions at $25 / 20^{\circ} \mathrm{C}$ day/night air temperature, with $75 \%$ relative humidity and a $16-\mathrm{h}$ photoperiod (350 $\mu \mathrm{mol} / \mathrm{m}^{2} / \mathrm{s}$ ). Two-month-old plants with 10 to 12 leaves were used for experiments.

Preparation of $\boldsymbol{P}$. chlamydospora culture filtrate. The fungal strain $P$. chlamydospora (SO44) was isolated from French $V$. vinifera vines displaying symptoms of Esca and maintained by the UMR SAVE (Institute of National Research of Agronomy, Bordeaux, France) monospore collection (18). It was cultivated on sterile potato dextrose agar (PDA; Sigma Chemical Co., St. Louis, MO) medium at $23^{\circ} \mathrm{C}$ in the dark. To obtain the culture filtrate, $P$. chlamydospora mycelium was added to 1 liter of modified Czapeck Dox liquid medium ( $3 \mathrm{~g}$ of $\mathrm{NaNO}_{3}$ per liter, $3 \mathrm{~g}$ of $\mathrm{KH}_{2} \mathrm{PO}_{4} 2 \mathrm{H}_{2} \mathrm{O}$ per liter, $0.5 \mathrm{~g}$ of $\mathrm{KCl}$ per liter, $30 \mathrm{~g}$ of D-glucose per liter, and $5 \mathrm{~g}$ of tartric acid per liter) at $\mathrm{pH} 3.2$. It was incubated in the dark at $22^{\circ} \mathrm{C}$ for 1 month. The culture medium was filtered through nylon membrane filter $(100 \mu \mathrm{m})$ and stored at $-20^{\circ} \mathrm{C}$. Before use, the filtrate was sterilized by filtration on cellulose membrane $(0.22 \mu \mathrm{m})$.

Elicitation of foliar cuttings by absorption of $\boldsymbol{P}$. chlamydospora culture filtrate. To discriminate the potentially different defense responses between grapevine plants poorly susceptible to Esca and susceptible ones, we used an elicitation model system mimicking some of the events occurring in the leaves of an Escaaffected plant (Fig. 1). The newly developed stem of a 2-monthold grapevine foliar cutting was excised at its base. This cut stem was dipped for $24 \mathrm{~h}$ at $25 \pm 1^{\circ} \mathrm{C}$ in $10 \mathrm{ml}$ of fungal culture filtrate. The control treatment consisted in the absorption of Czapek liquid medium alone. Treated cut stems were placed under controlled conditions at $25 / 20^{\circ} \mathrm{C}$ day/night air temperature and a $16 \mathrm{~h}$ photoperiod $\left(350 \mu \mathrm{mol} / \mathrm{m}^{2} / \mathrm{s}\right)$. At least five plants were used per treatment and each experiment was repeated in triplicate. At different time points, the three youngest leaves were collected, frozen in liquid nitrogen, and stored at $-80^{\circ} \mathrm{C}$ until analysis. Analysis of defense responses in leaves was then carried out. To validate the elicitation system, the filtrate was tested at 1,2,10, and $20 \%$, and the accumulation of two stilbenoids, trans-resveratrol and transpiceid, was monitored after $24 \mathrm{~h}$ of treatment in the leaves of a susceptible grapevine cultivar ('Cabernet Sauvignon'). At 20\%, a drastic phytotoxic effect of brown leaf necrosis occurred. No visual leaf symptom was noted in elicited plants with 1,2 , and $10 \%$ of fungal filtrate, as in control plants. Filtrate at 1 and $2 \%$ failed to induce stilbene synthesis significantly, whereas the treatment at $10 \%$ triggered a 6- and 2.5-fold greater accumulation of trans-resveratrol and trans-piceid, respectively, compared with control plants. Therefore, this $10 \%$ concentration of $P$. chlamydospora filtrate was used for the subsequent experiments. Leaves of treated plants were collected in liquid nitrogen after $0,3,6,12$, 18 , and $24 \mathrm{~h}$ of treatment for further analyses.

RNA extraction and quantification of gene expression by reverse transcription-quantitative polymerase chain reaction. The leaves were ground in presence of liquid nitrogen and the resulting powder was used for RNA extraction. Total RNA was extracted from leaf samples as described by Reid (42). Contaminating DNA in RNA samples was removed by incubating $15 \mu \mathrm{g}$ of total RNA with 10 units of RNase free DNase I according to the manufacturer's instructions (Promega Corp.). Proteins were extracted with phenol/chloroform/isoamylalcohol (25:24:1). The mixture was then centrifuged at $13,000 \mathrm{rpm}$ for $5 \mathrm{~min}$ at room temperature. To the supernatant $(250 \mu \mathrm{l}), 25 \mu \mathrm{l}$ of $3 \mathrm{M} \mathrm{NaOAc}$ (pH 5.2) and $625 \mu \mathrm{l}$ of absolute ethanol were added, mixed, and then stored at $-80^{\circ} \mathrm{C}$ for at least $2 \mathrm{~h}$. RNA pellet was collected at $13,000 \mathrm{rpm}$ at $4^{\circ} \mathrm{C}$ for $30 \mathrm{~min}$ and was dissolved in $15 \mu \mathrm{l}$ of DEPCtreated water. The integrity of the total RNA was checked by electrophoresis on $1.2 \%$ agarose gel containing $0.01 \%$ GelRed (Interchim, Montluçon, France). PCR amplifications with actin primers were carried out on RNA samples to control for the absence of genomic DNA. DNase-treated RNA $(1 \mu \mathrm{g})$ was reverse-transcribed using the ImProm-II reverse transcription system (Promega Corp.) according to the manufacturer's instructions. To determine the mRNA copy number of studied genes, reverse transcriptionquantitative polymerase chain reaction (RT-qPCR) was performed using the MyiQ detection system (Bio-Rad) and SYBR Green Quantitect (Qiagen). PCR reactions were carried out in triplicate in 96-well plates $(25 \mu \mathrm{l}$ per well) in a reaction buffer containing $1 \times$ SYBR Green Quantitect (Qiagen) with a 1:10 dilution of reverse-transcribed RNA. After denaturation at $95^{\circ} \mathrm{C}$ for $15 \mathrm{~min}$, amplification was performed in a two-step procedure: $15 \mathrm{~s}$ of denaturation at $95^{\circ} \mathrm{C}, 30 \mathrm{~s}$ of annealing at $60^{\circ} \mathrm{C}$ and $30 \mathrm{~s}$ of extension at $72^{\circ} \mathrm{C}$, with a total of 45 cycles. For each pair of primers, the PCR efficacy was comprised between 80 and $100 \%$. To check the specificity of the PCR product, melting curves were analyzed for each data point. Transcript levels were calculated as described by Arrieta-Montiel et al. (6) using the standard curve method from triplicate data, with EFI gene as internal control and control leaves (at time zero) as reference sample. The standard

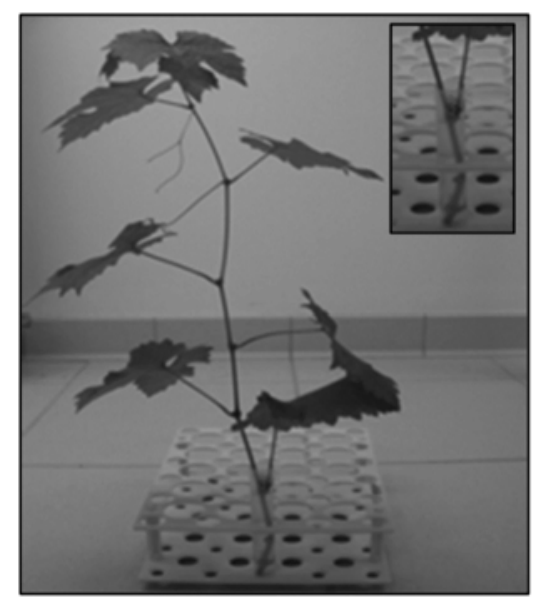

Fig. 1. Elicitation model system consisting of grapevine cuttings absorbing a culture filtrate of Phaemoniella chlamydospora, a causal agent of Esca. 
curve was constructed using templates of known copy number for target sequence: serial dilutions of cloned target sequence in pGEM-T easy vector (Promega Corp.) were used. The number of copies in each dilution was calculated with the following formula: (number of moles) $\left(6.02 \times 10^{23}\right)=$ number of copies. All standard samples were assayed in triplicate. The copy number of the sample was estimated by plotting the threshold cycle ( $\mathrm{Ct}$ values) against the logarithm of the starting copy number. The absolute copy number for each sample was calculated from standard curves using the $\mathrm{Ct}$ value and was normalized against grapevine $E F 1$ gene as internal control and control leaves as reference sample. The gene-specific primers are indicated in Table 1. Relative gene expression was obtained with the formula: fold induction $=2^{-[\Delta \Delta \mathrm{Ct}]}$, where $\Delta \Delta \mathrm{Ct}=[\mathrm{Ct}$ GI (unknown sample) $-\mathrm{Ct} \mathrm{EF} 1$ (unknown sample)] - [Ct GI (reference sample) - Ct EF1 (reference sample)]. $\mathrm{GI}$ is the gene of interest and EF1 is the grapevine EF1 gene used as internal control. The reference sample is the sample chosen to represent $1 \times$ expression of the gene of interest (e.g., leaves sampled at $0 \mathrm{~h}$ time) (51).

Quantification of stilbenes. Freeze-dried leaves were finely powdered. Stilbenes were extracted from $100 \mathrm{mg}$ of leaves overnight with $\mathrm{MeOH}(10 \mathrm{ml})$ at $4^{\circ} \mathrm{C}$. After centrifugation $(3,500 \mathrm{rpm}$, $10 \mathrm{~min}$ ), $4 \mathrm{ml}$ of the supernatant was concentrated and then prepurified on a Sep-Pak C18 cartridge (Waters) to remove chlorophylls. After elution with methanol $90 \%$ (vol/vol), the extract was evaporated to dryness $\left(<40^{\circ} \mathrm{C}\right)$. Leaf extracts were then dissolved in $1 \mathrm{ml}$ of methanol $50 \%$ ( $\mathrm{vol} / \mathrm{vol})$. Samples were filtered through nylon membrane filters (Titan 2, $0.45 \mu \mathrm{m}$, ICS). During sample preparation, extracts were protected from light to avoid photochemical isomerization of trans-stilbenes to $\mathrm{cis}$ forms. Analysis of stilbenes $(100 \mu \mathrm{l})$ was performed by HPLC on a $250 \times 4 \mathrm{~mm}$ Prontosil C18 (Ultrasep ES100 RP18, $5 \mu \mathrm{m}$ ) reverse-phase C18 column (Bischoff Chromatography, Leonberg, Germany) protected by a guard column of the same material. Separation was performed at a flow rate of $1 \mathrm{ml} / \mathrm{min}$ with a mobile phase composed of (A) $\mathrm{H}_{2} \mathrm{O}$ : TFA $1 \%(97.5 / 2.5$, vol/vol) and (B) ACN: A $(80 / 20, \mathrm{vol} / \mathrm{vol})$. The run was set as follows: 0 to $13 \mathrm{~min}$, from 14 to $18 \% \mathrm{~B} ; 13$ to $15 \mathrm{~min}, 18 \% \mathrm{~B} ; 15$ to $34 \mathrm{~min}$, from 18 to $32 \% \mathrm{~B}$; 34 to $36 \mathrm{~min}, 32 \% \mathrm{~B} ; 36$ to $40 \mathrm{~min}$, from 32 to $40 \% \mathrm{~B} ; 40$ to $49 \mathrm{~min}$, from 40 to $80 \% \mathrm{~B}$; 49 to $50 \mathrm{~min}$, from 80 to $100 \% \mathrm{~B}$; and 50 to $56 \mathrm{~min}, 100 \% \mathrm{~B}$. Fluorimetric detection was performed at $\lambda \mathrm{ex}=300 \mathrm{~nm}$ and $\lambda \mathrm{em}=390 \mathrm{~nm}$ (Fluorescence Detector Prostar 363; Varian). Stilbene contents were estimated from calibration curves prepared with pure standards. trans-Resveratrol and transpiceid (trans-resveratrol 3-O-beta-glucoside) were purchased from Sigma Chemical. trans- $\varepsilon$-Viniferin was purified from woody material and characterized by nuclear magnetic resonance and mass spectrometry as previously described (52).

Statistical analysis was performed using Kruskal-Wallis analysis of variance (Statistica 10, StatSoft, Inc.). $P$ values of $\leq 0.05$ were considered significantly different.

\section{RESULTS}

Stilbenoid accumulation in leaves of the three treated cultivars. Three grapevine cultivars were studied: 'Cabernet
Sauvignon', which is susceptible to Esca, and 'Carignan' and 'Merlot', which are less susceptible. At several time points after the treatment of the grapevine cuttings by $P$. chlamydospora filtrate at $10 \%$, trans-resveratrol, trans-piceid, and $\varepsilon$-viniferin contents were quantified (Fig. 2) in the leaves. We monitored these stilbenoids because trans-resveratrol and $\varepsilon$-viniferin have been reported to display a substantial antifungal activity and can be used as indicators of resistance to disease (29). The accumulation of trans-piceid was quantified because it is a nontoxic glycosylated derivative of resveratrol, which could be a form of resveratrol storage (9). First, all three cultivars contained around 10-fold more trans-piceid than the two other stilbenoid forms, trans-resveratrol and $\varepsilon$-viniferin, even without elicitation. Second, at the beginning of the experiment $(0 \mathrm{~h})$, no difference in stilbenoid content was observed between the three cultivars. Thereafter, however, the trans-piceid content in the two less susceptible cultivars started to accumulate at 3 and $6 \mathrm{~h}$ posttreatment in 'Carignan' and 'Merlot', respectively. After 18 h, it reached a plateau (around 130 and $180 \mathrm{nmol} / \mathrm{g}$ dry weight [DW], respectively) and remained high at least until $24 \mathrm{~h}$. In 'Cabernet Sauvignon' leaves, trans-piceid levels did not evolve during elicitation (about $50 \mathrm{nmol} / \mathrm{g} \mathrm{DW}$ ). Therefore, trans-piceid content was higher in the less susceptible cultivar leaves than in those of the susceptible cultivar. For example, at $18 \mathrm{~h}$, there was a two-fold difference. Considering trans-resveratrol, levels began to increase significantly after $3 \mathrm{~h}$ of treatment in all cultivars. In 'Merlot', they rose until $12 \mathrm{~h}(30 \mathrm{nmol} / \mathrm{g} \mathrm{DW})$, remained stable until $18 \mathrm{~h}$ (plateau), and decreased at $24 \mathrm{~h}$ to baseline. In 'Carignan' and 'Cabernet Sauvignon', trans-resveratrol also accumulated transiently but slightly to only about 4-fold of baseline (from 2 to 3 to 8 to $12 \mathrm{nmol} / \mathrm{g} \mathrm{DW}$ ) instead of 10 -fold in 'Merlot'. However, the increase appeared earlier in 'Carignan' $(12 \mathrm{~h})$ than in 'Cabernet Sauvignon' (18 h). Regarding $\varepsilon$-viniferin, no significant changes occurred in any of the three cultivars with a value remaining around $6 \mathrm{nmol} / \mathrm{g} \mathrm{DW}$.

Transcript accumulation of defense genes in leaves of the three treated cultivars. The expression pattern of six genes involved in grapevine defense was analyzed using RT-qPCR. Two genes involved in the biosynthesis of polyphenolic compounds were studied, especially stilbenoids: a phenylalanine ammonialyase $(P A L)$ gene encoding the first enzyme of the pathway and a stilbene synthase (STS) gene encoding the enzyme responsible for the synthesis of stilbenes like resveratrol, one of the main grapevine phytoalexins. Four genes encoding PR proteins were also investigated: an acidic class IV chitinase $(C H I T 4 C)$ gene, a serineprotease inhibitor $(P I N)$ gene, a polygalacturonase-inhibiting protein $(P G I P)$ gene, and a beta-1,3-glucanase $(G L U)$ gene.

In leaves collected at $0 \mathrm{~h}$, no significant difference in transcript content of any of the genes was detected between the three cultivars (Fig. 3). In 'Merlot' and 'Carignan' leaves, the expression of the $P A L$ gene was rapidly and transiently up-regulated. The induction peaked at $3 \mathrm{~h}$ in 'Carignan' and at $6 \mathrm{~h}$ in 'Merlot' with a maximal intensity 1,600- and 1,800-fold higher than in the control (0 h), respectively. In 'Cabernet Sauvignon', no significant $P A L$ transcript accumulation was observed during the 24-h incubation period. The expression profile of the STS gene was similar in the

TABLE 1. Gene accession numbers and sequences of gene primers used for real-time quantitative polymerase chain reaction

\begin{tabular}{|c|c|c|c|}
\hline Names & NCBI accession numbers or TC $\mathrm{DFCI}^{\mathrm{a}}$ & Forward primer $\left(5^{\prime}-3^{\prime}\right)$ & Reverse primer $\left(5^{\prime}-3^{\prime}\right)$ \\
\hline$P A L$ & X755967 & TGCTGACTGGTGAAAAGGTG & CGTTCCAAGCACTGAGACAA \\
\hline STS & AF274281 & GTGGGGCTCACCTTTCATT & CTGGGTGAGCAATCCAAAAT \\
\hline PGIP & AF305093 & ACGGAACTTGTTCCAGTTTGAT & CGATTGTAACTCACGTTCAGGA \\
\hline$P I N$ & AY156047 & GCAGAAACCATTAAGAGGGAGA & TCTATCCGATGGTAGGGACACT \\
\hline CHIT4C & AY 137377 & GGCGACGAATCCATTTATGTTA & CGGAACAAGGGTTTCATAATTC \\
\hline$G L U$ & AF239617 & TACCTCTTTGCCATGTTTGATG & AGTACTTCGGCTGTTTGTTTGG \\
\hline EF1 & TC31634 & TGAAGAATGGTGATGCTGGA & CAACAGTTTGACGCATGTCC \\
\hline
\end{tabular}

a NCBI, National Center for Biotechnology Information. TC DFCI, tentative consensus number according to the Dana-Farber Cancer Institute. 
three grapevine cultivars and was characterized by two induction peaks. However, according to the cultivar, the first peak occurred at a different time point and had a different level of induction. It was maximal after $3 \mathrm{~h}$ of elicitation in 'Merlot' and 'Carignan' with a 25- to 40-fold increase, whereas it appeared only at $6 \mathrm{~h}$ in 'Cabernet Sauvignon' and with a very slight transcript accumulation around 5-fold higher than the control $(0 \mathrm{~h})$. Besides, the $P A L$ gene was around 50-fold more up-regulated than the STS gene.

In the case of PR proteins, the induction level of the PGIP and $G L U$ genes was higher than that of the PIN and CHIT4C genes. The PIN gene was transiently induced and reached a maximum at $18 \mathrm{~h}$ in 'Merlot' and 'Carignan' (around 20-fold higher), while no significant change occurred in 'Cabernet Sauvignon'. There was even a slight initial increase in the PIN gene after $6 \mathrm{~h}$ of treatment in Merlot. The PGIP gene was also transiently up-regulated in 'Carignan' and 'Merlot' and peaked at 3 and $6 \mathrm{~h}$, respectively. Moreover, PGIP transcript accumulation in 'Carignan' was very large and was 4-fold higher than in 'Merlot'. No transcript accumulation of PGIP was noted in 'Cabernet Sauvignon'. The CHI $4 \mathrm{C}$ gene was transiently induced at 3 and $12 \mathrm{~h}$, with a more intense peak at $3 \mathrm{~h}$. No up-regulation of $C H I 4 C$ was observed in 'Merlot' or 'Cabernet Sauvignon'. We noted two GLU induction peaks in 'Merlot' and 'Carignan'. The first was transient at $6 \mathrm{~h}$ and was 2-fold lower in 'Carignan'. The second occurred at $24 \mathrm{~h}$ and was higher than the first peak at $6 \mathrm{~h}$ (2- and 8-fold greater in 'Merlot' and 'Carignan', respectively). This GLU transcript content was similar in the two less susceptible cultivars. However, even though the $G L U$ gene was stimulated in the leaves of treated 'Cabernet Sauvignon' plants, this up-regulation was very faint at $6 \mathrm{~h}$ and more intense at $18 \mathrm{~h}$, but was still around 3-fold lower than that of the two less susceptible grapevines.

\section{DISCUSSION}

These results demonstrate that grapevine cultivars like 'Merlot' and 'Carignan', which are thought to be less susceptible to Esca on the basis of their leaf symptom expression in vineyard, are able to activate several defense responses faster and more strongly than a susceptible grapevine, 'Cabernet Sauvignon', after elicitation. These responses are those of the phenylpropanoid pathway (induction of $P A L$ and STS genes and accumulation of stilbene compounds) and some PR proteins (up-regulation of PGIP, PIN, $C H I 4 C$, and $G L U$ genes).

To investigate whether distinct cultivar-related defense responses could explain these differences, we worked with an easily reproducible, short-term system. The model consisted in using excised grapevine stems absorbing a $P$. chlamydospora culture filtrate in which we monitored defense marker responses in their leaves. We used green stems because they are partially dedicated to phloem and xylem flows. Furthermore, xylem vessels allow the migration of secreted fungal compounds from the trunk (where pathogens develop) to the distal part of the canopy like the leaves (14), where foliar disease symptoms are expressed. Secreted fungal compounds can be produced in vitro in culture medium so culture filtrates are often used for disease resistance selection $(20,47$, 48).We used the $P$. chlamydospora culture filtrate for several reasons. $P$. chlamydospora is one of the main agents of leaf stripe disease and occurs since the early stages of the disease (10). Moreover, its culture medium has been well characterized $(5,10$, 45). Indeed, the presence of some phytotoxic compounds has been demonstrated in a liquid culture of $P$. chlamydospora as proteins $(36,43)$, a polysaccharide named pullulan, and two main naphtalenones, scytalone and isosclerone (12). The latter compounds can migrate through xylem vessels to leaves (14). Little is known about the ability of these phytotoxic molecules to act as elicitor molecules or their ability to trigger defense responses. Nevertheless, Luini et al. (36) observed that a polypeptide fraction secreted by $P$. chlamydospora can trigger elicitation responses in grapevine cell suspensions: induction of NADPH oxidase (an enzyme activated early after the perception of an elicitor and leading to the formation of reactive oxygen species) and PAL (an enzyme leading to the synthesis of phytoalexins) activities. Moreover, these defense reactions were dose-dependent. The $P$. chlamydospora culture filtrate that we used mainly contains secreted fungal compounds because we filtered it in such a way that the mycelium was not retained. However, we cannot rule out that it did not contain mycelium fragments, which can themselves elicit an increase in stilbene synthesis and induce genes encoding PR proteins (34). In the present study, we did not try to isolate elicitor compounds and/or to characterize the composition of the culture filtrate because we did not intend to study the action of individual
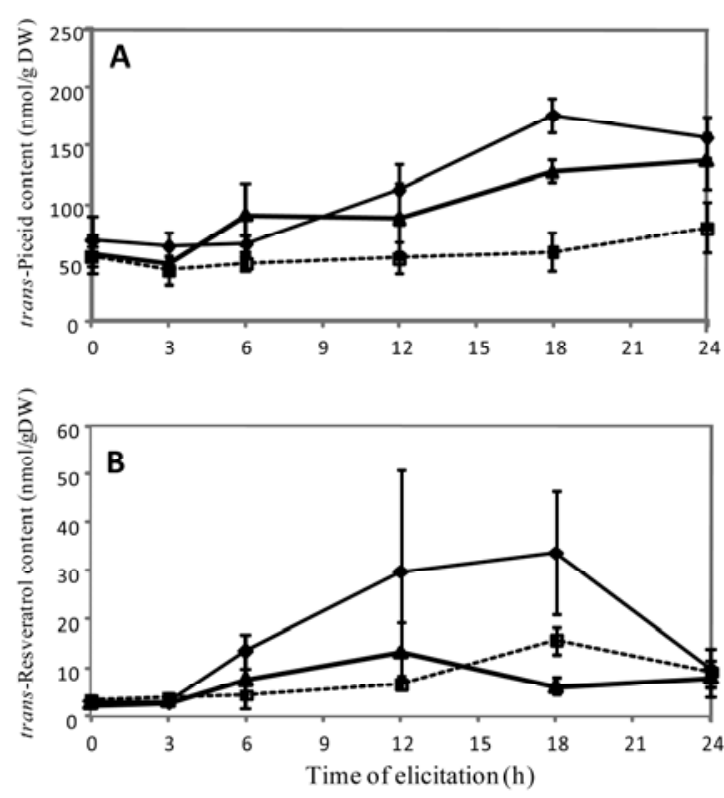
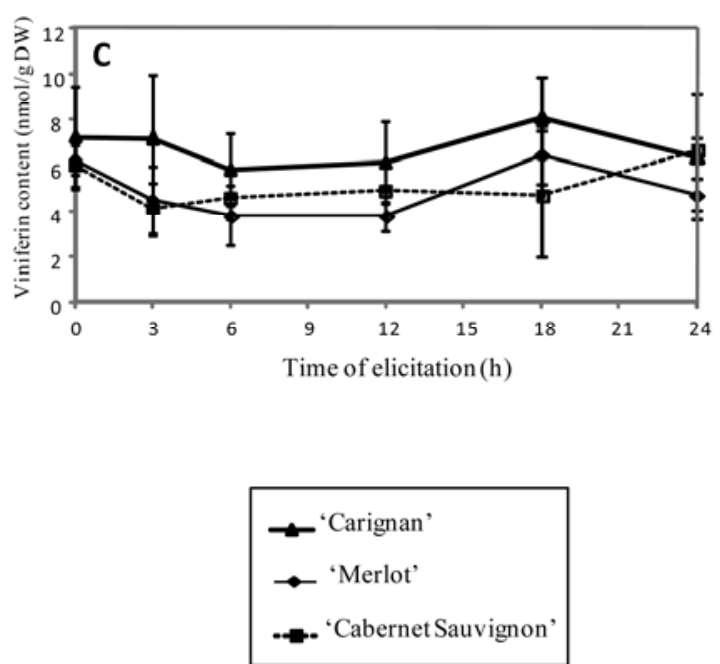

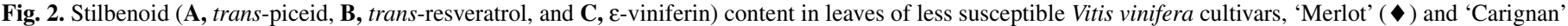

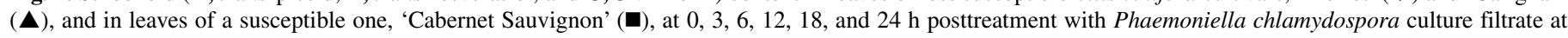
$10 \%$. Results represent the means of two independent experiments of three replicates each ( \pm standard deviation). 
compounds. Rather, our aim was to observe the elicitation effect of total secreted fungal molecules potentially synthesized by $P$. chlamydospora fungus in vivo, thus acting as a whole in the host plant. Nevertheless, we checked that the P. chlamydospora culture filtrate we used contained such molecules by validating its ability to induce the production of grapevine phytoalexins in the susceptible cultivar ('Cabernet Sauvignon').

To compare the defense responses of grapevine cultivars with different levels of susceptibility towards Esca, we needed to select typical defense markers. In grapevine, the most frequently observed and best characterized active defense mechanisms are the accumulation of phenolics and the synthesis of extracellular enzymes (29). Indeed, high amounts of resveratrol and its derivatives are found in infected woody tissues $(3,4,39)$, the PAL enzyme is activated in grapevine cells treated with $P$. chlamydospora secreted polypeptides (36), and the expression of the two genes PAL and STS, which are involved in the phenylpropanoid pathway, is induced in pre-apoplectic leaves of apparently healthy vines and is amplified during the apoplectic event $(33,37)$.

Moreover, during the days preceding leaf symptoms, other stress-related genes are stimulated, notably CHIT4C $(33,37)$, $G L U$, and PR6 (37). For these reasons, we monitored defense indicators like the expression profile of PGIP gene encoding a polygalacturonase-inhibiting protein, a gene typically induced by various stimuli including pathogen attack (30).

In the leaves of the three grapevine cultivars treated by the $P$. chlamydospora culture filtrate, that the $P A L$ and STS genes were induced, as were $G L U$ and PGIP, two PR protein genes
(Fig. 3). This indicates that these cultivars can perceive some elicitor signals (e.g., fungal toxic and/or plant defense compounds) and react by triggering defense mechanisms as in preapoplectic leaves of Esca-diseased grapevines in the vineyard $(33,37)$. Besides, the fungal filtrate treatment triggered similar grapevine defense responses as did other elicitor treatments, e.g., oligogalacturonide addition on grapevine cells (7) and methyljasmonate spray on leaves (9). We also noted a biphasic STS induction profile, as already reported after Vitis vinifera elicitation (11). Interestingly, gene induction occurred earlier ( $3 \mathrm{~h}$ posttreatment) in our model experiment than after inoculation. Indeed, expression of defense-related genes often reached a maximum at $12 \mathrm{~h}$ postinfection (26). This difference could be due to the plant's perception of fungal metabolites which might occur sooner or later according to the model. It is almost immediate in our elicitation system, whereas it occurs later in inoculated plants owing to a latency period consecutive to the fungal development in the plant. As several defense marker events were induced in the grapevine leaves after the elicitation method that we used, we are able validate this experimental model.

Considering the defense responses of the different grapevine cultivars that we studied, the two less susceptible cultivars 'Merlot' and 'Carignan' responded to the filtrate treatment more strongly and more rapidly by stimulating stilbene accumulation and by overexpressing $P A L$ and $S T S$ genes and all PR protein genes studied (GLU, PIN, CHIT4C, and PGIP) compared with 'Cabernet Sauvignon', the susceptible cultivar (Fig. 3). Such differences in defense response between grapevine cultivars have
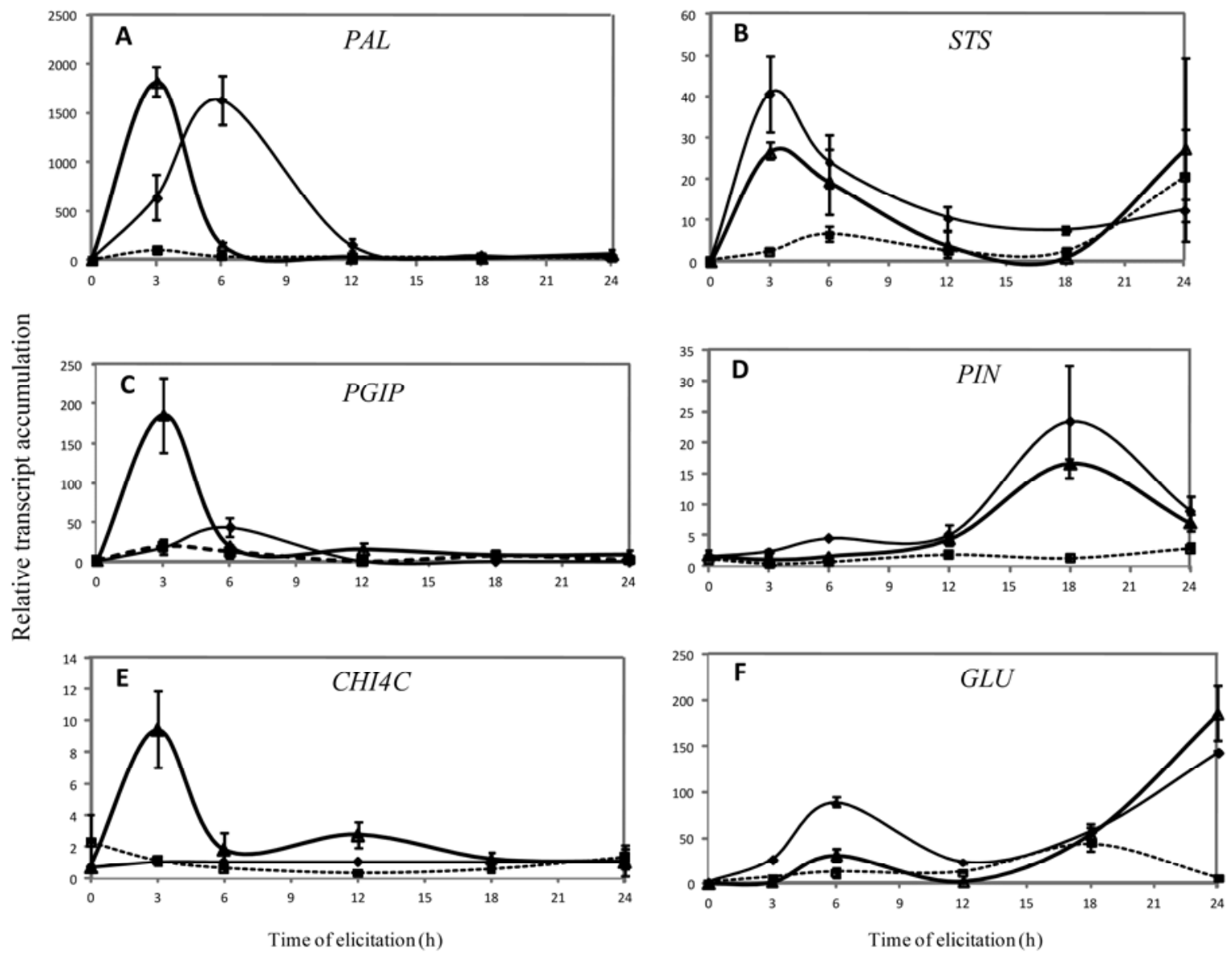

Fig. 3. Transcript accumulation of defense genes in Vitis vinifera leaves of 'Merlot' ( $\bullet$ ), 'Carignan' $(\mathbf{\Delta})$ and 'Cabernet Sauvignon' ( $\mathbf{\square})$ during the $24 \mathrm{~h}$ period of treatment with Phaemoniella chlamydospora filtrate at $10 \%$. Genes of interest encode the following proteins: A, a phenylalanine ammonia lyase ( $P A L)$, B, a stilbene synthase (STS), C, a polygalacturonase-inhibiting protein (PGIP), D, a serine protease inhibitor (PIN), E, an acidic class IV chitinase (CHIT4c), and $\mathbf{F}$, a beta-1,3-glucanase $(G L U)$. Analyses were performed by reverse transcription quantitative polymerase chain reaction. Transcript levels were calculated by using the standard curve method from triplicate data, with grapevine EF1 gene as internal control and leaves at time zero as reference sample. Results are means \pm standard deviations of two experiments of three replicates each. 
not been reported to date. Considering the involvement of phenolics in the level of susceptibility, this hypothesis was previously suggested by several authors $(3,4,33,36,37,39)$. Moreover, Bruno and Sparapano (13) showed that the highest content of total and recurring phenolics (e.g., resveratrol) was found in the calli of the $V$. vinifera 'Matilde', a cultivar with an intermediate level of susceptibility to Esca, while 'Italia', a susceptible cultivar, had the lowest content. The net accumulation of phenolic compounds within the plant tissues infected by pathogens might contribute to the plant's ability to deal better with fungal colonization by creating an inhibitory barrier. This idea is widely suggested by other plant interaction systems $(2,11)$. Besides, in vitro assays showed that numerous simple phenolic acids displayed an antimicrobial activity on fungi involved in grapevine decline and/or an inhibitory effect on fungal enzymes catalysing wood degradation (21,41). Similar observations were reported with resveratrol $(14,40)$ and we recently showed that several stilbenoids, such as resveratrol and some of its derivatives, impact the development of some Esca fungi (31).

Considering the PR proteins (GLU, PIN, CHIT4C, and PGIP), their genes tended to be highly stimulated in the less susceptible cultivars after filtrate treatment. They accumulated in response to pathogen invasion and their causative role in plant resistance is supported by the evidence reviewed by Edreva (23): greater accumulation in inoculated resistant plants compared with susceptible ones; strong constitutive expression of PRs in plants with a high level of natural disease resistance; increased resistance to pathogens in transgenic plants overexpressing PR genes; and accumulation of PRs in plants in which resistance is locally or systemically induced. Moreover, many PR members exhibit antimicrobial activity (23), suggesting their direct role in disease resistance. Other stress conditions such as abiotic ones can also trigger the induction of PR proteins. Van Loon (50) speculated that the role of such nonspecific induction can protect plant cellular structures. This protection could either correspond to a physical stabilization of sensitive membranes or macromolecules, and/or to a chemical process triggered to keep in check potentially harmful saprophytic microorganisms on tissue surfaces or in intercellular spaces.

In our study, grapevine elicitation induced an earlier and higher PR accumulation in 'Merlot' and 'Carignan', the two cultivars in which a lower percentage of vines symptomatic to Esca was observed in vineyard, compared with 'Cabernet Sauvignon', the susceptible cultivar. We hypothesize that 'Merlot' and 'Carignan' are less impacted by Esca fungi, at least by $P$. chlamydospora, thanks to their ability to trigger better protection of the whole plant. Such a defense mechanism could be similar to that previously suggested by van Loon (50). Moreover, 'Merlot' and 'Carignan' responded faster and more strongly. Such a difference in defense response time is a classical feature observed in plant disease resistance phenomena, since the defense mechanisms in incompatible plant-pathogen interactions are activated more rapidly than in compatible ones (16). Besides, we hypothesize that defense factors similar to those involved in resistance are involved in the stronger response to Esca of the less susceptible grapevine cultivars 'Merlot' and 'Carignan'. Moreover, the stronger defense responses (stilbenes and PR proteins) observed in leaves of elicited grapevine cultivars less susceptible to Esca might occur not only in the leaves of Esca-infected plants but also in the xylem vessels, the fungal-colonized compartments. Indeed, grapevine xylem sap contains many metabolites such as phenolic compounds (14), in particular stilbenes, and defense proteins like chitinases and beta-1,3-glucanases (1). A recent study reported that the xylem sap of grapevine species less susceptible to Pierce's disease, a disease caused by a xylem-confined bacteria, presents an abundant amount of PR proteins (8).

To conclude, this is the first demonstration that an earlier and greater induction of the phenylpropanoid pathway and some PR proteins is triggered in grapevine cultivars less susceptible to Esca than in a susceptible one. Validation of these findings with more cultivars could be carried out in the future. Furthermore, the study confirms the value of our simple grapevine elicitation system using cut stems absorbing a culture filtrate of $P$. chlamydospora. It could become a relevant model for rapidly assessing grapevine defense responses.

\section{ACKNOWLEDGMENTS}

We thank L. Guérin-Dubrana, M.-F. Corio-Costet, and G. Comont (INRA, Villenave d'Ornon, France) for providing the fungal material and R. Cooke for revising this manuscript.

\section{LITERATURE CITED}

1. Aguero, C. B., Thorne, E. T., Ibanez, A. M., Gubler, W. D., and Dandekar, A. M. 2008. Xylem sap proteins from Vitis vinifera L. Chardonnay. Am. J. Enol. Vitic. 59:306-311.

2. Alonso-Villaverde, V., Voinesco, F., Viret, O., Spring, J. L., and Gindro, K. 2011. The effectiveness of stilbenes in resistant Vitaceae: Ultrastructural and biochemical events during Plasmopara viticola infection process. Plant Physiol. Biochem. 49:265-274.

3. Amalfitano, C., Agrelli, D., Arrigo, A., Mugnai, L., Surico, G., and Evidente, A. 2011. Stilbene polyphenols in the brown red wood of Vitis vinifera cv. Sangiovese affected by "Esca proper". Phytopathol. Mediterr. 50:224-235.

4. Amalfitano, C., Evidente, A., Surico, G., Tegli, S., Bertelli, E., and Mugnai, L. 2000. Phenols and stilbene polyphenols in the wood of Escadiseased grapevine. Phytopathol. Mediterr. 39:178-183.

5. Andolfi, A., Mugnai, L., Luque, J., Surico, G., Cimmino, A., and Evidente, A. 2011. Phytotoxins produced by fungi associated with grapevine trunk diseases. Toxins 3:1569-1605.

6. Arrieta-Montiel, M., Lyznik, A., Woloszynska, M., Janska, H., Tohme, J., and Mackenzie, S. 2001. Tracing evolutionary and developmental implication of mitochondrial stoichiometric shifting in the common bean. Genetics 158:851-886.

7. Aziz, A., Heyraud, A., and Lambert, B. 2004. Oligogalacturonide signal transduction, induction of defense-related responses and protection of grapevine against Botrytis cinerea. Planta 218:767-774.

8. Basha, S. M., Mazhar, H., and Vasanthaiah, H. K. N. 2010. Proteomic approach to identify unique xylem sap proteins in Pierce's diseasetolerant Vitis species. Appl. Biochem. Biotechnol. 160:932-944.

9. Belhadj, A., Saigne, C., Telef, N., Cluzet, S., Bouscaut, J., Corio-Costet, M. F., and Mérillon, J. M. 2006. Methyl jasmonate induces defense responses in grapevine and triggers protection against Erysiphe necator. J. Agric. Food Chem. 54:9119-9125.

10. Bertsch, C., Ramírez-Suero, M., Magnin-Robert, M., Larignon, P., Chong, J., Abou-Mansour, E., Spagnolo, A., Clément, C., and Fontaine, F. 2013. Grapevine trunk diseases: Complex and still poorly understood. Plant Pathol. 62:243-265.

11. Borie, B., Jeandet, P., Parize, A., Bessis, R., and Adrian, M. 2004 Resveratrol and stilbene synthase mRNA production in grapevine leaves treated with biotic and abiotic phytoalexin elicitors. Am. J. Enol. Vitic. 55:60-64.

12. Bruno, G., and Sparapano, L. 2006. Effects of three Esca-associated fungi on Vitis vinifera L.: I. Characterization of secondary metabolites in culture media and host responses to the pathogens in calli. Physiol. Mol. Plant Pathol. 69:209-223.

13. Bruno, G., and Sparapano, L. 2006. Effects of three Esca-associated fungi on Vitis vinifera L.: II. Characterization of biomolecules in xylem sap and leaves of healthy and diseased vines. Physiol. Mol. Plant Pathol. 69:195208.

14. Bruno, G., and Sparapano, L. 2007. Effects of three Esca-associated fungi on Vitis vinifera L.: V. Changes in the chemical and biological profile of xylem sap from diseased cv. Sangiovese vines. Physiol. Mol. Plant Pathol. 71:210-229.

15. Calzarano, F., Seghetti, L., Del Carlo, M., and Cichelli, A. 2004. Effect of Esca on the quality of berries, musts and wines. Phytopathol. Mediterr. 43:125-135.

16. Chen, Y., and Halterman, A. 2011. Phenotypic characterization of potato late blight resistance mediated by the broad-spectrum resistance gene $R B$. Phytopathology 101:263-270.

17. Christen, D., Schönmann, S., Jermini, M., Strasser, R. J., and Défago, G. 2007. Characterization and early detection of grapevine (Vitis vinifera) stress responses to Esca disease by in situ chlorophyll fluorescence and comparison with drought stress. Environ. Exp. Bot. 60:504-514. 
18. Comont, G., Corio-Costet, M. F., Larignon, P., and Delmotte, F. 2010. AFLP markers reveal two genetic groups in the French population of the grapevine fungal pathogen Phaeomoniella chlamydospora. Eur. J. Plant Pathol. 127:451-464.

19. Crous, P. W., and Gams, W. 2000. Phaeomoniella chlamydospora gen. et comb. Nov., a causal organism of Petri grapevine decline and Esca. Phytopathol. Mediterr. 39:112-118.

20. Cvikrová, M., Malá, J., Hrubcová, M., Eder, J., and Foretová, S. 2008. Induced changes in phenolic acids and stilbenes in embryogenic cell cultures of Norway spruce by culture filtrate of Ascocalyx abietina. J. Plant Dis. Prot. 115:57-62.

21. Del Río, J. A., Gomez, P., Baidez, A., Fuster, M. D., Ortuno, A., and Frias, V. 2004. Phenolic compounds have a role in the defence mechanism protecting grapevine against the fungi involved in Petri disease. Phytopathol. Mediterr. 43:87-94.

22. Dong, X. 1998. SA, JA, ethylene, and disease resistance in plants. Curr. Opin. Plant Biol. 1:316-323.

23. Edreva, A. 2005. Pathogenesis-related proteins: Research progress in the last 15 years. Gen. Appl. Plant Physiol. 31:105-124.

24. Feliciano, A. J., Eskalen, A., and Gubler, W. D. 2004. Differential susceptibility of three grapevine cultivars to Phaeoacremonium aleophilum and Phaeomoniella chlamydospora in California. Phytopathol. Mediterr. 43:66-69.

25. Fischer, M. 2002. A new wood-decaying basidiomycete species associated with Esca of grapevine: Fomitiporia mediterranea (Hymenochaetales). Mycol. Prog. 1:299-313.

26. Fung, R. W. M., Gonzalo, M., Fekete, C., Kovacs, L. G., He, Y., Marsh, E., McIntyre, L. M., Schachtman, D. P., and Qiu, W. 2008. Powdery mildew induces defense-oriented reprogramming of the transcriptome in a susceptible but not in a resistant grapevine. Plant Physiol. 146:236-249.

27. Fussler, L., Kobes, N., Bertrand, F., Maumy, M., Grosman, J., and Savary, S. 2008. A characterization of grapevine trunk diseases in France from data generated by the National Grapevine Wood Diseases Survey. Phytopathology 98:571-579.

28. Glazebrook, J. 2005. Contrasting mechanisms of defense against biotrophic and necrotrophic pathogens. Annu. Rev. Phytopathol. 43:205-227.

29. Jeandet, P., Douillet-Breuil, A. C., Bessis, R., Debord, S., Sbaghi, M., and Adrian, M. 2002. Phytoalexins from the Vitaceae: Biosynthesis, phytoalexin gene expression in transgenic plants, antifungal activity, and metabolism. J. Agric. Food Chem. 50:2731-2741.

30. Joubert, D. A., de Lorenzo, G., and Vivier, M. A. 2013. Regulation of the grapevine polygalacturonase-inhibiting protein encoding gene: Expression pattern, induction profile and promoter analysis. J. Plant Res. 126:267-28.

31. Lambert, C., Bisson, J., Waffo-Téguo, P., Papastamoulis, Y., Richard, T., Corio-Costet, M. F., Mérillon, J. M., and Cluzet, S. 2012. Phenolics and their antifungal role in grapevine wood decay: Focus on the Botryosphaeriaceae family. J. Agric. Food Chem. 60:11859-11868.

32. Larignon, P., and Dubos, B. 1997.Fungi associated with Esca disease in grapevine. Eur. J. Plant Pathol. 103:147-157.

33. Letousey, P., Baillieul, F., Perrot, G., Rabenoelina, F., Boulay, M., Vaillant-Gaveau, N., Clément, C., and Fontaine, F. 2010. Early events prior to visual symptoms in the apoplectic form of grapevine Esca disease. Phytopathology 100:424-431.

34. Lima, M. R. M., Ferreres, F., and Dias, A. C. P. 2012. Response of Vitis vinifera cell cultures to Phaemoniella chlamydospora: Changes in phenolic production, oxidative state and expression of defence-related genes. Eur. J. Plant Pathol. 132:133-146.

35. Lorrain, B., Ky, I., Pasquier, G., Jourdes, M., Dubrana, L. G., Gény, L., Rey, P., Donèche, B., and Teissedre, P. L. 2012. Effect of Esca disease on the phenolic and sensory attributes of Cabernet Sauvignon grapes, musts and wines. Aust. J. Grape Wine Res. 18:64-72.
36. Luini, E., Fleurat-Lessard, P., Rousseau, L., Roblin, G., and Berjeaud, J. M. 2010. Inhibitory effects of polypeptides secreted by the grapevine pathogens Phaeomoniella chlamydospora and Phaeoacremonium aleophilum on plant cell activities. Physiol. Mol. Plant Pathol. 74:403-411.

37. Magnin-Robert, M., Letousey, P., Spagnolo, A., Rabenoelina, F., Jacquens, L., Mercier, L., Clément, C., and Fontaine, F. 2011. Leaf stripe form of Esca induces alteration of photosynthesis and defence reactions in presymptomatic leaves. Funct. Plant Biol. 38:856-866.

38. Marchi, G., Peduto, F., Mugnai, L., Di Marco, S., Calzarano, F., and Surico, G. 2006. Some observations on the relationship on manifest and hidden Esca to rainfall. Phytopathol. Mediterr. 45:117-126.

39. Martin, N., Vesentini, D., Rego, C., and Monteiro, S. 2009. Phaeomoniella chlamydospora infection induces changes in phenolic compounds content in Vitis vinifera. Phytopathol. Mediterr. 48:101-116.

40. Mazullo, A., Di Marco, S., Osti, F., and Cesari, A. 2000. Bioassays on the activity of resveratrol, pterostilbene and phosphorous acid towards fungi associated with Esca of grapevine. Phytopathol. Mediterr. 39:357-365.

41. Mugnai, L., Graniti, A., and Surico, G. 1999. Esca (black measles) and brown wood-streaking: Two old and elusive diseases of grapevines. Plant Dis. 83:404-418.

42. Reid, K. E., Olsson, N., Schlosser, J., Peng, F., and Lund, S. T. 2006. An optimized grapevine RNA isolation procedure and statistical determination of reference genes for real-time RT-PCR during berry development. BMC Plant Biol. 6:27.

43. Santos, C., Fragoeiro, S., Valentim, H., and Phillips, A. 2006. Phenotypic characterisation of Phaeoacremonium and Phaemoniella strains isolated from grapevines: Enzyme production and virulence of extra-cellular filtrate on grapevine calluses. Sci. Hort. 107:123-130.

44. Spagnolo, A., Magnin-Robert, M., DilezitokoAlayi, T., Cilindre, C., Mercier, L., Schaeffer-Reiss, C., Van Dorsselaer, A., Clément, C., and Fontaine, F. 2012. Physiological changes in green stems of Vitis vinifera L. cv. Chardonnay in response to Esca proper and apoplexy revealed by proteomic and transcriptomic analyses. J. Proteome Res. 11:461-475.

45. Sparapano, L., Bruno, G., and Graniti, A. 2000. Effects on plants of metabolites produced in culture by Phaeoacremonium chlamydosporum, P. aleophilum and Fomitiporia punctata. Phytopathol. Mediterr. 39:169177.

46. Surico, G., Marchi, G., Braccini, P., and Mugnai, L. 2000. Epidemiology of Esca in some vineyards in Tuscany (Italy). Phytopathol. Mediterr. 39:190-205.

47. Thakur, M., Sharma, D. R., and Sharma, S. K. 2002. In vitro selection and regeneration of carnation (Dianthus caryophyllus L.) plants resistant to culture filtrate of Fusarium oxysporum. Plant Cell Rep. 20:825-828.

48. Trevisan, M. T. S., Valdivia, A. C. R., Scheffer, J. J. C., and Verpoorte, R. 1997. Enzyme activities in cell suspension cultures of two hop cultivars after elicitation by a fungal culture filtrate. Biotech. Lett. 19:207-211.

49. Valtaud, C., Foyer, C. H., Fleurat-Lessard, P., and Bourbouloux, A. 2009. Systemic effects on leaf glutathione metabolism and defence protein expression caused by Esca infection in grapevines. Funct. Plant Biol. 36:260-279.

50. Van Loon, L. C. 2010. Occurrence and properties of plant pathogenesisrelated proteins. Pages 1-19 in: Pathogenesis-related proteins in plants. S. K. Datta and S. Muthukrishnan, eds. CRC Press, Boca Raton, FL.

51. Winer, J., Jung, C. K. S., Shackel, I., and Williams, P. M. 1999. Development and validation of real-time quantitative reverse transcriptasepolymerase chain reaction for monitoring gene expression in cardiac myocytes in vitro. Anal. Biochem. 270:41-49.

52. Zga, N., Papastamoulis, Y., Toribio, A., Richard, T., Delaunay, J.C., Jeandet, P., Renault, J. H., Monti, J. P., Mérillon, J. M., and Waffo-Téguo, P. 2009. Preparative purification of antiamyloidogenic stilbenoids from Vitis vinifera (Chardonnay) stems by centrifugal partition chromatography. J. Chrom. B. 877:1000-1004. 